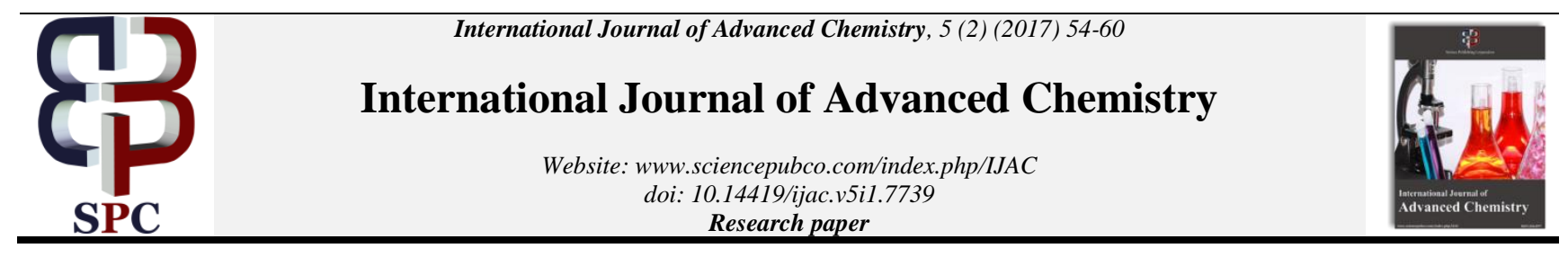

\title{
Spectral characterization, microbial activities and toxicity study of some newly synthesized hydrazone derivatives
}

\author{
N. Kalaiarasi, S. Manivarman * \\ Assistant Professor, PG \& Research Department of Chemistry, Government Arts College, C-Mutlur, Chidambaram, Tamil Nadu, India \\ *Corresponding author E-mail: drsmgac@gmail.com
}

\begin{abstract}
Hydrazone derivatives of 2-Thioxodihyropyrimidine-2-dione were synthesized by addition of thiobarbituric acid with phenyl hydrazine, dinitrophenyl hydrazine, semicarbazide, thiosemicarbazide and benzohydrazide respectively. Structures of these synthesized compounds are characterized by means of UV, IR, Proton-NMR, Carbon- NMR. Finally the hydrazone derivatives synthesized are screened for biological activities namely antibacterial and antifungal activities. Also in addition the toxicity studies of the compounds are also performed.
\end{abstract}

Keywords: Thiobarbituric; IR; NMR; Antimicrobial; Toxicity.

\section{Introduction}

Hydrazones are important class of organic compounds used in the field of development of new drugs. They play major role in synthetic chemistry hence researchers are interested to synthesis the hydrazone derivatives by using different substituents and to evaluate their biological activities. It plays an important role in improving the antitumour selectivity and toxicity profile of antitumour agents by forming drug carrier systems employing suitable carrier proteins (Kratz et al. 1988). They are reported to possess antimicrobial, antitubercular, anticonvulsant, analgesic, antiinflammatory, antiplatelet, anticancer, antifungal, antiviral, antitumor, antibacterial and antimalarial activities (Imramovsky et al. 2007; Janin et al. 2007; Salgin-Goksen et al. 2007; Bhalla et al. 2006; Silva et al. 2004; Savini et al. 2004; Bijev et al. 2006; Abdel- Aal et al. 2006; El-Hawash et al. 2006; Cocco et al. 2005; Malhotra et al. 2014). In the present study some new derivatives of 2-thioxodihydropyrimidine derivatives have been synthesized by nucleophilic substitution elimination reaction and evaluated for structural and microbial activities.

\section{Materials and method}

The chemical used for this synthesize were purchased from sigma Aldrich and Merck chemical company. Melting points were determined on a Mettler FP51 melting point apparatus and are uncorrected. UV spectra are recorded using ELICO-BL222 spectrophotometer $\lambda \max \mathrm{nm}$ using spectral grade methanol solvent. Infrared spectra $\mathrm{KBr}, 4000-400 \mathrm{~cm}^{-1}$ have been recorded on SHIMADZU Fourier transform spectrophotometer. NMR spectra recorded using Bruker $300 \mathrm{MHz}$ spectrometer for ${ }^{1} \mathrm{H}-\mathrm{NMR}$ and $100 \mathrm{MHz}$ spectrometer for ${ }^{13} \mathrm{C}-\mathrm{NMR}$, with DMSO- $\mathrm{d}^{6}$ as solvent. Synthesized compounds were evaluated for their in-vitro antibacterial and antifungal activity against pathogenic bacterial and fungal species by disc diffusion method. Toxicity study was carried out using MTT assay method.

\section{Experimental}

\subsection{Synthesis of thiobarbituric acid (TBA)}

About $6 \mathrm{~g}(0.25 \mathrm{~mol})$ of sodium metal is dissolved in $200 \mathrm{ml}$ of ethanol. To this solution $15 \mathrm{~g}(0.25 \mathrm{~mol})$ of thiourea and $40 \mathrm{ml}$ of diethyl malonate is added. The reaction mixture is refluxed for $6 \mathrm{hrs}$ in an oil bath and then vacuum distillated to make ethanol recovery. The clear solution thus obtained is filtered, cooled in ice bath overnight and the resulting solution is acidified with $\mathrm{HCl}$. The crude product obtained is collected, washed with $50 \mathrm{ml}$ water and dried in oven at $105-110^{\circ} \mathrm{C}$ for nearly $4 \mathrm{hrs}$. The obtained white coloured precipitate Thiobarbituric acid-TBA is purified by recrystallization with ethanol. (M.P - $243^{\circ} \mathrm{C}$, yield- $80 \%$ ).

\subsection{Synthesis of 2-thioxodihydropyrimidine-2-dione derivatives}

Equimolar mixture of synthesized thiobarbituric acid and substituents (phenyl hydrazine, dinitrophenyl hydrazine, semicarbazide, thiosemicarbazide, benzohydrazide) are dissolved in $25 \mathrm{ml}$ ethanol separately and the content is poured into a RB fixed with a condenser and refluxed for $4 \mathrm{hrs}$ in an oil bath, then the reaction mixture is stand overnight and the precipitate obtained is filtered washed with ethanol and dried to obtain the derivatives, the product thus obtained is recrystallized to obtain pure product. The schematic procedures for synthesis of thiobarbituric acid and 2thioxodihydropyrimidine-2-dione derivatives are shown in Scheme. I \& Scheme. II of the picture Fig.1. The mechanisms of formation are digrammatically presented in Fig. 2.

The symbol $\mathrm{X}$ in the linkage X-NH- $\mathrm{NH}_{2}$ represented in Scheme-II of the Fig. 1 is probably mentioned below.

$\mathrm{X}=\mathrm{i})-\mathrm{C}_{6} \mathrm{H}_{5}$; ii) $-\mathrm{C}_{6} \mathrm{H}_{3}\left(\mathrm{NO}_{2}\right)_{2}$; iii) $-\mathrm{CONH}_{2}$; IV) $-\mathrm{CSNH} 2$; V)$\mathrm{COC}_{6} \mathrm{H}_{5}$ 


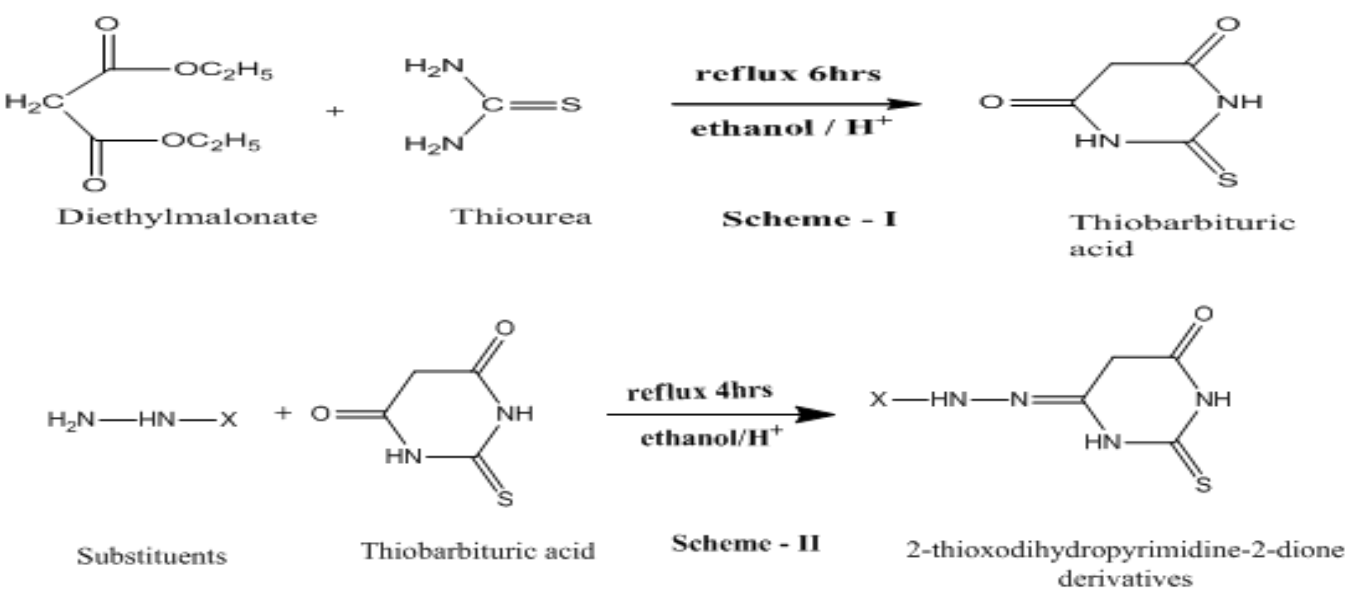

Fig. 1: Schematic Diagram of Synthesis.
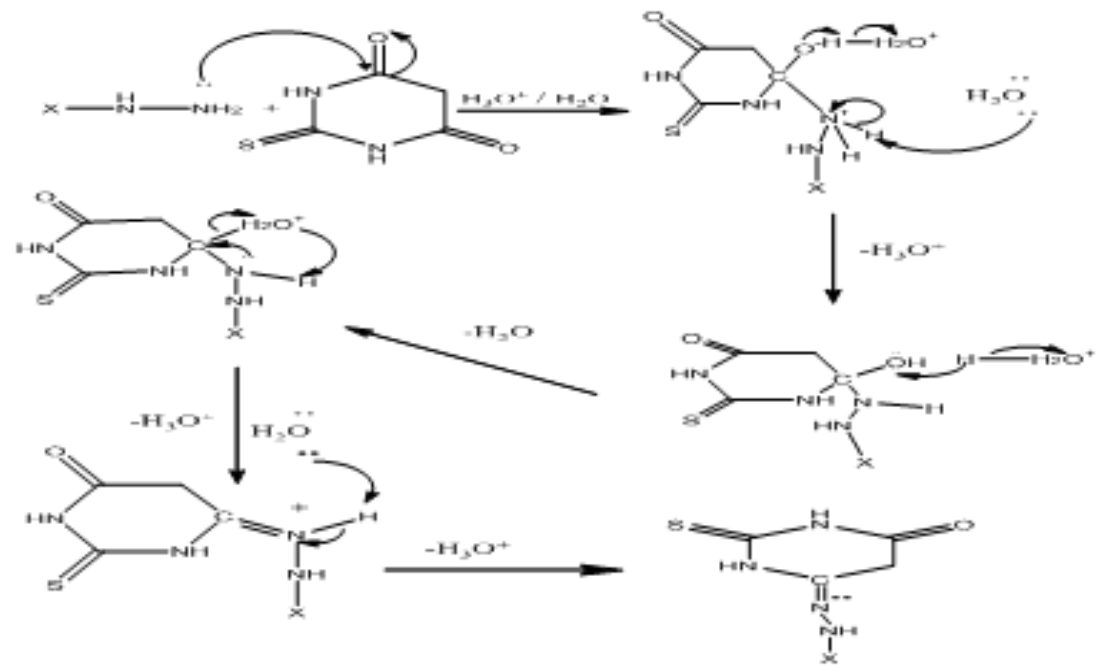

Fig. 2: Mechanism of Synthesis.

\section{Result and discussion}

The physical parameters such as melting point, yield and colour of the compound are noted. Structures of the compound were elucidated by IR, Raman and NMR as assigned below according to the literature (Long 2004, Wong 2015). The spectral assignments of the synthesized parent compound and their substituted derivatives are discussed below.

\subsection{Structural elucidation of the synthesized compound by spectral assignments}

\subsubsection{2-Thioxodihyropyrimidine-2-dione (TBA)}

${ }^{1} \mathrm{HNMR}$ spectra ( $\delta$ value) - $\mathrm{NH}$ (RING)- $12.1-12.2, \mathrm{CH}_{2}$ methylene4.979; ${ }^{13}$ C-NMR spectra (ppm) - 163, 175.08, 30.53; Yield - 82\%; M.P. $-243^{\circ} \mathrm{C}$; Colour - white powder.

4.1.2. 6 - 2 - phenylhydrazono -2 - thioxotetrahydropyrimidin - 4 (1H) - one (PHTTO)

UV spectra (nm) - 345, 302, 238; IR Spectra $\left(\mathrm{Cm}^{-1}\right)$ - 1697(C=O), $3186(\mathrm{~N}-\mathrm{H}), \quad 1163(\mathrm{C}=\mathrm{S}), \quad 1625(\mathrm{C}=\mathrm{N}), \quad 3014(\mathrm{Ar}-\mathrm{H}), \quad 2870$,

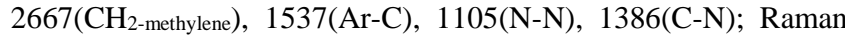
Spectra $\left(\mathrm{Cm}^{-1}\right)-1709(\mathrm{C}=\mathrm{O}), 3107(\mathrm{~N}-\mathrm{H}), 1156(\mathrm{C}=\mathrm{S}), 1680(\mathrm{C}=\mathrm{N})$,

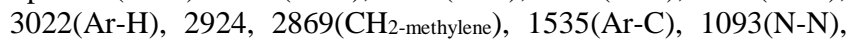
1391(C-N); ${ }^{1} \mathrm{HNMR}$ spectra ( $\delta$ value)- $\mathrm{NH}$ (Hydrazide) $-5.0, \mathrm{NH}$ (RING)- 9.946, 10.922, $\mathrm{CH}_{2}$ methylene- 1.163 , Ar-H- 8.75, 8.178.20, 7.60-7.62; ${ }^{13} \mathrm{C}-\mathrm{NMR}$ spectra ppm $155.74,163.45,149.14,44.21,134.20,123.45,127.48,129.53,115.55$. Yield - $78 \%$; M.P. - $180^{\circ} \mathrm{C}$; Colour - light yellow powder.

\subsubsection{6-(2-(2, 4-dinitrophenyl) hydrazono)-2 thioxotetrahydropyrimidin- $4(1 \mathrm{H})$-one}

UV spectra (nm)- 343.5, 306.5; IR Spectra $\left(\mathrm{Cm}^{-1}\right)-1653(\mathrm{C}=\mathrm{O})$, 3292(N-H), 1122(C=S), 1593(C=N), 3118(Ar-H), 2924, 2835( $\left(\mathrm{CH}_{2}\right.$ - methylene), 1421(C-N), 1292( $\left.\mathrm{NO}_{2}\right)$; Raman Spectra $\left(\mathrm{Cm}^{-1}\right)-3320(\mathrm{~N}-\mathrm{H}), 1124(\mathrm{C}=\mathrm{S}), 1600(\mathrm{C}=\mathrm{N}), 3268(\mathrm{Ar}-\mathrm{H}), 3086$, $2972\left(\mathrm{CH}_{2}\right.$ - methylene $), 1427(\mathrm{C}-\mathrm{N}), 1259\left(\mathrm{NO}_{2}\right) ;{ }^{1} \mathrm{HNMR}$ spectra $(\delta$ value)- $\mathrm{NH}$ (Hydrazide) $-8.541, \mathrm{NH}_{\text {(RING) }}-8.775,11.087, \mathrm{CH}_{2}$ methylene- 1.321, Ar-H- 7.25-7.30, 7.42, 7.55; ${ }^{13} \mathrm{C}-\mathrm{NMR}$ spectra (ppm) -172.67, 175.67,168.38, 71.84, 150.0,144.54,131.97, 163.20. Yield - $72 \%$; M.P. - $170^{\circ} \mathrm{C}$; Colour - Dark reddish brown.

\subsubsection{2-(6-0xo-2-thioxotetrahydropyrimidin-4(1H)-ylidene) hydrazinecarboxamide}

UV spectra (nm)- 355.5, 314, 246; IR Spectra $\left(\mathrm{Cm}^{-1}\right)-1739$ $(\mathrm{C}=\mathrm{O}), 3379(\mathrm{~N}-\mathrm{H}), 1099(\mathrm{C}=\mathrm{S}), 1622(\mathrm{C}=\mathrm{N}), 3047,2870\left(\mathrm{CH}_{2-}\right.$ methylene), 1427(N-N), 1340,1303(C-N),1533, 1496( $\left.\mathrm{NH}_{2}\right)$; Raman Spectra $\left(\mathrm{Cm}^{-1}\right)-1729 \quad(\mathrm{C}=\mathrm{O}), \quad 3218(\mathrm{~N}-\mathrm{H}), \quad 1101(\mathrm{C}=\mathrm{S})$, $1651(\mathrm{C}=\mathrm{N}), \quad 3105,2869\left(\mathrm{CH}_{2-}\right.$ methylene $), 1440(\mathrm{~N}-\mathrm{N}), 1367(\mathrm{C}-$ $\mathrm{N}), 1534\left(\mathrm{NH}_{2}\right) ;{ }^{1} \mathrm{H}-\mathrm{NMR}$ spectra ( $\delta$ value) - $\mathrm{NH}$ (Hydrazide) -5.040 , $\mathrm{NH}$ (RING)- 8.762, 11.10, $\mathrm{CH}_{2}$ methylene- $2.144, \mathrm{NH}_{2}-7.239 ;{ }^{13} \mathrm{C}-$ NMR spectra (ppm) -168.54, 183.53, 162.72, 30.65. Yield- 69\%; M.P. - $170^{\circ} \mathrm{C}$; Colour - Turbid white.

\subsubsection{2-(6-0xo-2-thioxotetrahydropyrimidin-4(1H)-ylidene) hydrazinecarbothioamide}

UV spectra (nm)- 385.5, 256; IR Spectra $\left(\mathrm{Cm}^{-1}\right)-1834(\mathrm{C}=\mathrm{O})$,

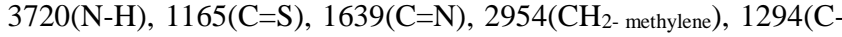


$\mathrm{N}), 1537\left(\mathrm{NH}_{2}\right)$; Raman Spectra $\left(\mathrm{Cm}^{-1}\right)-3255 \mathrm{~N}-\mathrm{H}, 1049(\mathrm{C}=\mathrm{S})$, 1604 $(\mathrm{C}=\mathrm{N}), 3180\left(\mathrm{CH}_{2}\right.$ - methylene $), 1301(\mathrm{C}-\mathrm{N}), 1517\left(\mathrm{NH}_{2}\right) ;{ }^{1} \mathrm{H}-\mathrm{NMR}$ spectra ( $\delta$ value)- $\mathrm{NH}_{\text {(Hydrazide) }}-7.908, \mathrm{NH}_{\text {(RING) }}$ 10.218, 11.923, $\mathrm{CH}_{2}$ methylene- 4.64, $\mathrm{NH}_{2}-9.48 ;{ }^{13} \mathrm{C}-\mathrm{NMR}$ spectra $(\mathrm{ppm})-$ 183.3, 175.39, 166.45, 154.81,82.49. Yield - $68 \%$; M.P. - $174^{\circ} \mathrm{C}$; Colour - Dark yellow.

\subsection{6. $\quad \mathrm{N}^{\prime}$-(6-0xo-2-thioxotetrahydropyrimidin-4(1H)-ylidene) Benzohydrazide}

UV spectra $(\mathrm{nm})-370.48,313.16,289.48$; IR Spectra $\left(\mathrm{Cm}^{-1}\right)$ $1799,1690(\mathrm{C}=\mathrm{O}), 3428(\mathrm{~N}-\mathrm{H}), 1014(\mathrm{C}=\mathrm{S}), 1600(\mathrm{C}=\mathrm{N}), 3155(\mathrm{Ar}-$ $\mathrm{H}), 2880,2669\left(\mathrm{CH}_{2}\right.$ - methylene $), 1528(\mathrm{Ar}-\mathrm{C}), 1106(\mathrm{~N}-\mathrm{N}), 1396(\mathrm{C}-$ $\mathrm{N})$; Raman Spectra $\left(\mathrm{Cm}^{-1}\right)$ - 1762,1723(C=O), 3470, $3298(\mathrm{~N}-\mathrm{H})$, 1002(C=S), 1673(C=N), 3005( $\mathrm{Ar}-\mathrm{H}), 2878 \quad\left(\mathrm{CH}_{2-}\right.$ methylene $)$, 1543(Ar-C), 1194(N-N), 1367(C-N); ${ }^{1} \mathrm{HNMR}$ spectra $\delta$ value- NH (Hydrazide) $-5.017, \mathrm{NH}$ (RING) - 7.964, 11.818, $\mathrm{CH}_{2}$ methylene- 3.533, Ar-H- 7.54-7.67; ${ }^{13} \mathrm{C}-\mathrm{NMR}$ spectra (ppm) -168.85, 175.31, $167.80,166.40,162.79,82.58,128.76-130.69$. Yield- 84\%; M.P. $168^{\circ} \mathrm{C}$; Colour - reddish white

\subsection{Microbial study}

Procedure:

About $10 \mathrm{mg}$ of newly synthesized 2-thioxodihydropyrimidine-2dione derivatives were dissolved in $1 \mathrm{ml}$ of DMSO solvent. Using $100 \mu \mathrm{ml}$ of solution, the discs have been impregnated and placed on the solidified Mueller Hinton Agar medium for antibacterial assay and Potato Dextrose agar medium for antifungal assay to find out the antimicrobial activity of the compounds on each organism. The antimicrobial sensitivity assay was performed by using (Bauer et al. 1966) disc diffusion technique. The antimicrobial activities of the derivatives have been studied against ten microorganisms five bacterial and five fungal organisms and the results have been discussed below.

\subsubsection{Antibacterial activity}

The synthesized 2- thioxodihydropyrimidine - 2 - dione derivatives are subjected to antibacterial activity revealed in Fig.3. The antibacterial activities of all the synthesized compounds have been studied against three gram positive pathogenic strains Bacillus substilis, streptococcus pyogene and Staphylococcus aureus and two gram negative strains Escherichia coli and Pseudomonas aeruginosa. Table 1 shows the zone of inhibition of the derivatives and the resultant clustered column chart is shown in Fig. 4.

The compound OTTHPYBH shows excellent activity against all fungal organisms. PHTTO and DNPHTTO shows good activity against all fungal species when compared with OTHHPYHC and OTTHPYHCT which show moderate activity for all, except for staphylococcus aureus which shows poor activity.

\subsubsection{Antifungal activity}

The antifungal activities of all the synthesized 2thioxodihydropyrimidine-2-dione derivatives have been studied against five fungal species namely, Aspergillus flavus, Aspergillus Niger, Fusarium oxysporum, penicillin chryogenum and Trigoderma viride by using disc diffusion method. Fig. 5 shows zone of inhibition of the derivatives and the resultant clustered column chart is shown in Fig. 6. From Table 2, most of the synthesized compounds in the present investigation have shown moderate to good activity against all the five fungal species probably.

The synthesized compound OTHHPYHC shows moderate activity against all five fungal species whereas PHTTO, DNPHTTO shows good to moderate activity against Penicillim chryogenum. OTTHPYHCT show very low activity against Aspergillus flavus, Aspergillus niger. OTTHPYBH shows poor activity against fungal species expect for Trigoderma veride which shows a mild activity.
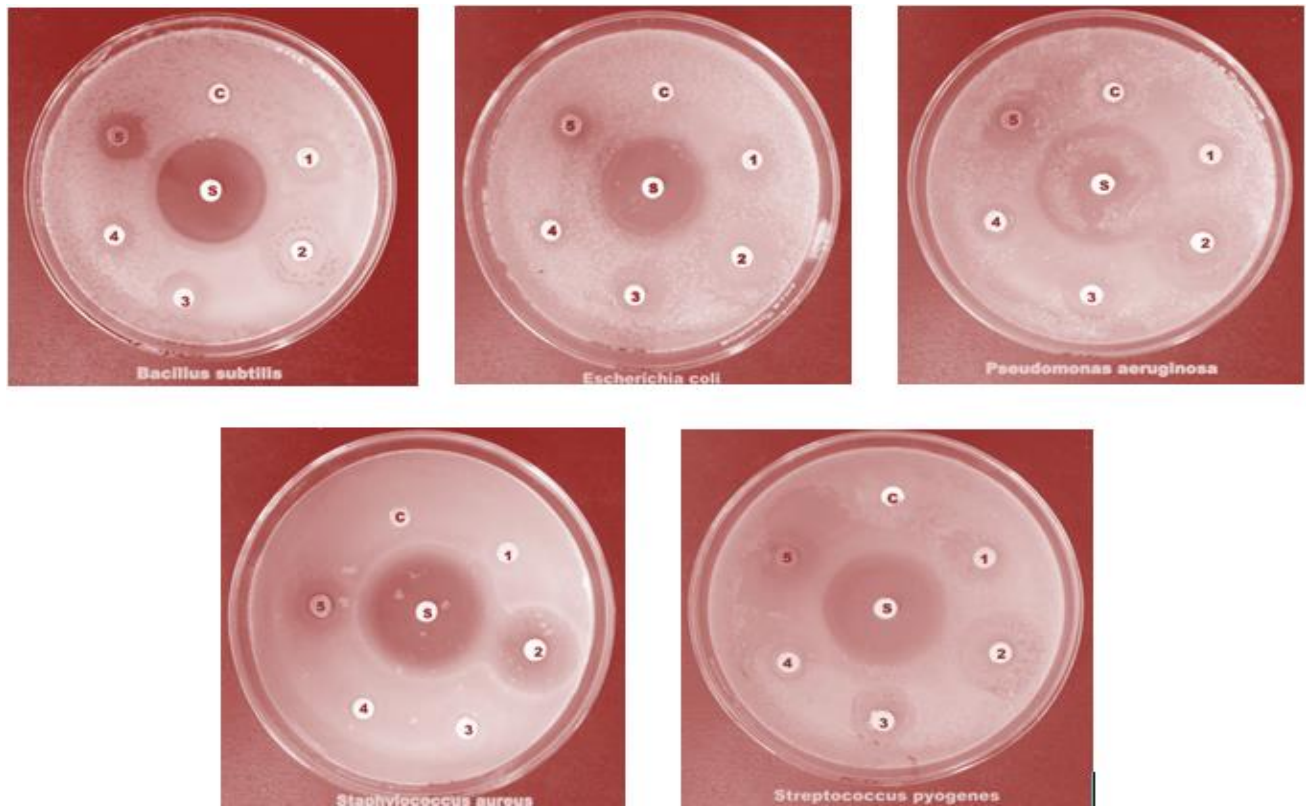

Fig. 3: Antibacterial activity of 2-thioxodihydropyrimidine-2-dione derivatives. 


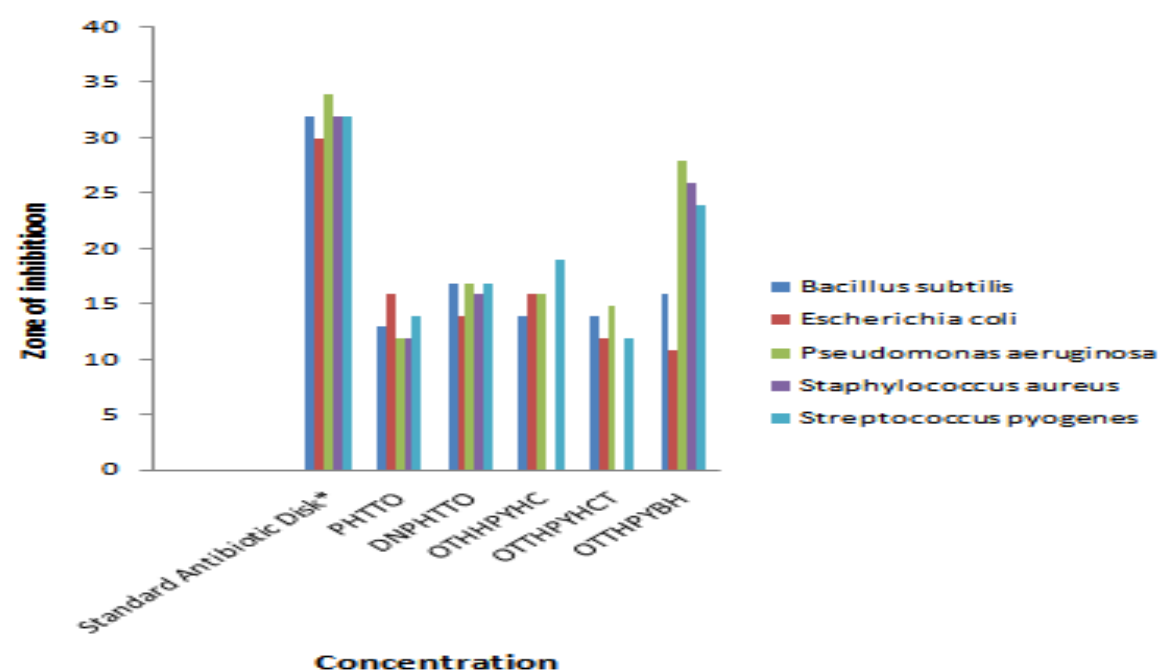

Fig. 4: Cluster Column Chart for Antibacterial Activity of 2-Thioxodihydropyrimidine-2-Dione Derivatives.

STANDARD: *CIPROFLOXACIN CONTROL: DMSO

Table 1: Antibacterial Activity [Disc Diffusion Method] of Hydrazone Derivatives of 2- Thioxodihydropyrimidine-2-Dione

\begin{tabular}{|c|c|c|c|c|c|c|}
\hline \multicolumn{2}{|c|}{ COMPOUND NAME } & \multirow{2}{*}{$\begin{array}{l}\text { Bacillus sub- } \\
\text { tilis } \\
32\end{array}$} & \multirow{2}{*}{$\begin{array}{l}\text { Escherichia coli } \\
30\end{array}$} & \multirow{2}{*}{$\begin{array}{l}\text { Pseudomonas aeru- } \\
\text { ginosa }\end{array}$} & \multirow{2}{*}{$\begin{array}{l}\begin{array}{l}\text { Staphylococcus } \\
\text { aureus }\end{array} \\
32\end{array}$} & \multirow{2}{*}{$\begin{array}{l}\text { Streptococcus py- } \\
\text { ogenes } \\
32\end{array}$} \\
\hline \multirow{6}{*}{ 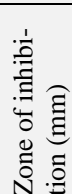 } & Ciprofloxacin* & & & & & \\
\hline & PHTTO & 13 & 16 & 12 & 12 & 14 \\
\hline & DNPHTTO & 17 & 14 & 17 & 16 & 17 \\
\hline & OTHНPYHC & 14 & 16 & 16 & - & 19 \\
\hline & OTTHРYНСТ & 14 & 12 & 15 & - & 12 \\
\hline & ОТТНРYВН & 16 & 11 & 28 & 26 & 24 \\
\hline
\end{tabular}
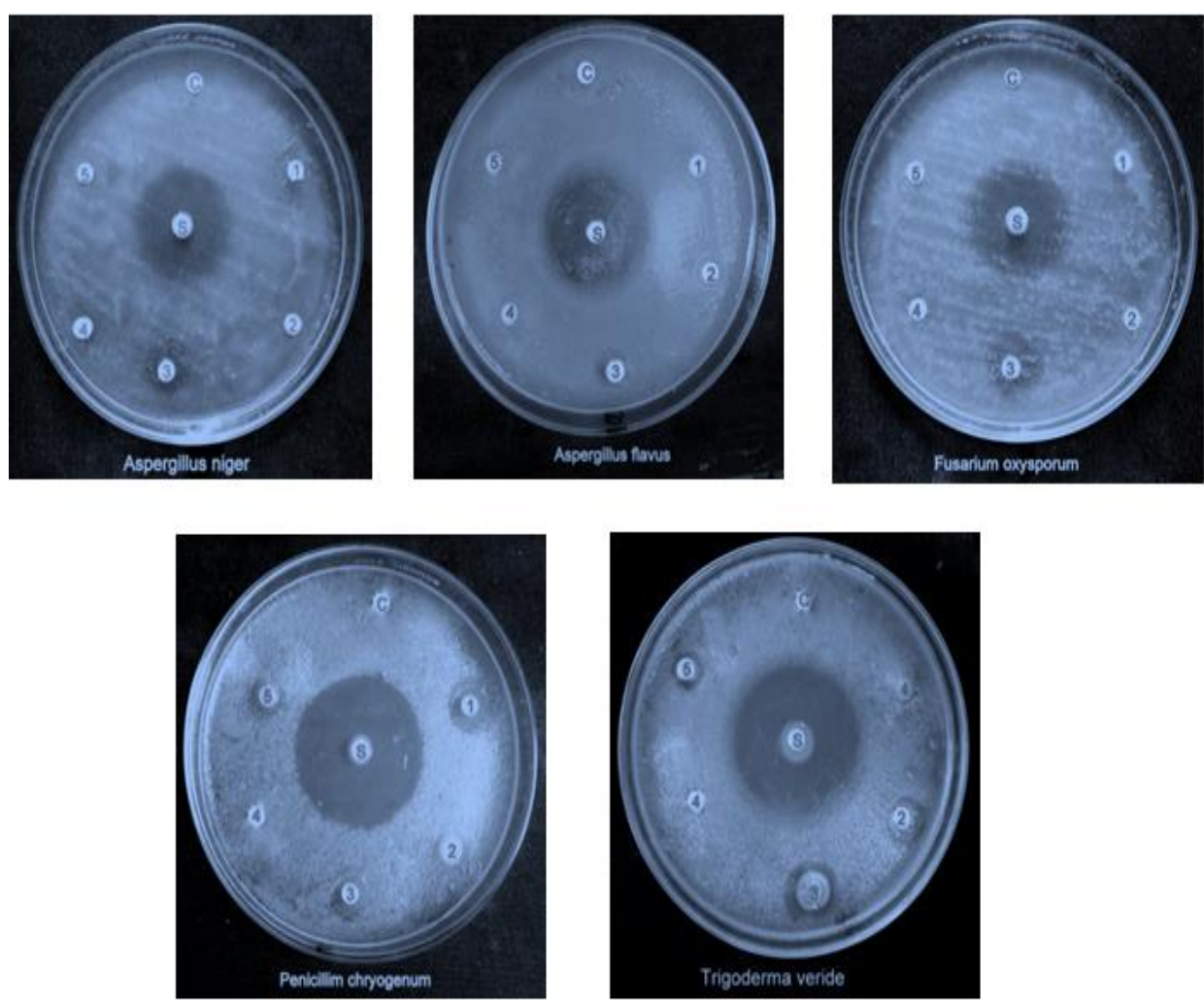

Fig. 5: Antifungal Activity of 2-Thioxodihydropyrimidine-2-Dione Derivatives. 


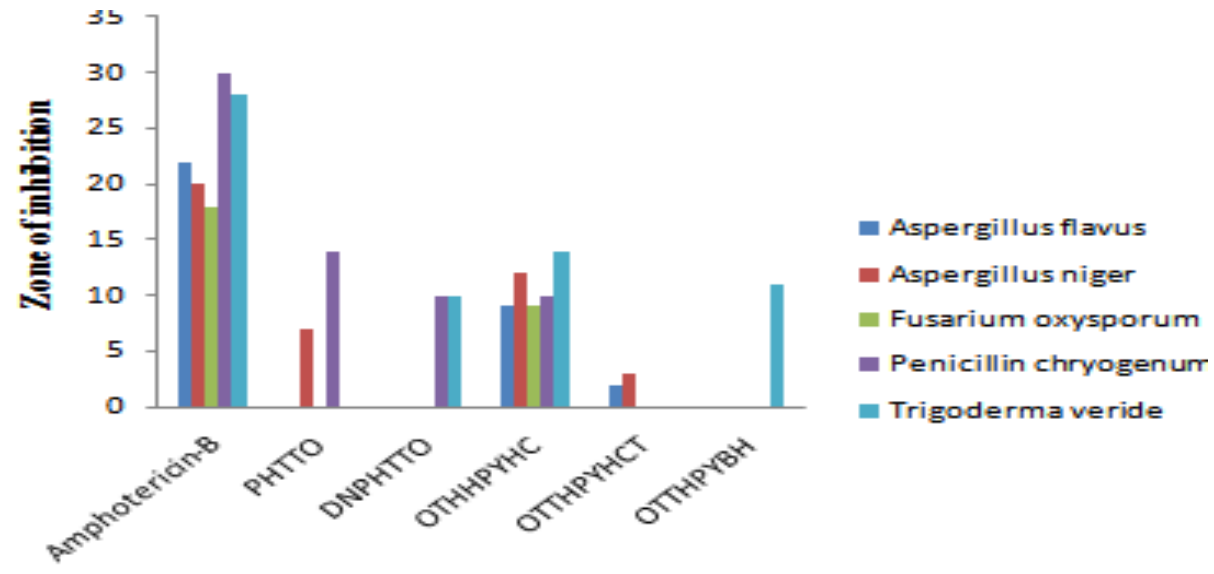

Concentration

Fig. 6: Cluster Column Chart for Antifungal Activity of 2-Thioxodihydropyrimidine-2-Dione Derivatives.

Standard: *Amphotericin-B Control: DMSO.

Table 2: Antifungal Activity [Disc Diffusion Method] of Hydrazone Derivatives of 2- Thioxodihydropyrimidine-2-Dione

\begin{tabular}{|c|c|c|c|c|c|c|}
\hline \multicolumn{2}{|c|}{ COMPOUND NAME } & Aspergillus flavus & Aspergillus niger & $\begin{array}{l}\text { Fusarium ox- } \\
\text { ysporum }\end{array}$ & $\begin{array}{l}\text { Penicillim } \\
\text { chryogenum }\end{array}$ & $\begin{array}{l}\text { Trigoderma } \\
\text { veride }\end{array}$ \\
\hline \multirow{5}{*}{ 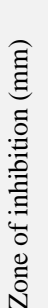 } & Amphotericin-B & 22 & 20 & 18 & 30 & 28 \\
\hline & РНTTO & - & 07 & - & 14 & - \\
\hline & DNPHTTO & - & - & - & 10 & 10 \\
\hline & ОТНHРYНC & 09 & 12 & 09 & 10 & 14 \\
\hline & ОТТНРҮВН & - & - & - & - & 11 \\
\hline
\end{tabular}

\subsection{Toxicity study}

MTT assay for cell viability:

The MTT assay is based on the application of MTT dye, which works with the action of mitochondrial enzyme. It is mainly performed to measure the functionality of human and animal cells. The MTT assay (Mossman 1983) is the best known method for determining mitochondrial dehydrogenase activity in the living cells. The mitochondrial enzymes are responsible for reduction of MTT a yellow tetrazolium dye MTT- 3-4, 5-dimethylthiazol-2-yl2, 5-diphenyltetrazolium bromide to a purple formazan product by NADH. MTT formazan is insoluble in water, and it forms purple needle-shaped crystals in the cells. Only viable cells will convert MTT and give a purple colour, whereas dead cells will not be able to convert MTT. Therefore prior to measuring the absorbance, an organic solvent is required to solubilize the crystals. Additionally, the cytotoxicity of MTT formazan makes it difficult to remove cell culture media from the plate wells due to floating cells with MTT formazan needles, giving significant well-to-well error (Alley \& Lieber 1984).

\section{PROCEDURE:}

Cells were maintained in DMEM medium, supplemented with $10 \%$ Fetal Bovine Serum, at $37^{\circ} \mathrm{C}$ in humidified atmosphere with $5 \% \mathrm{CO}_{2}$. Colo 320 cells were plated in 96 well flat bottom tissue culture plates at a density of approximate $11.2 \times 10^{4}$ cells / well and allowed to attach overnight at $37^{\circ} \mathrm{C}$. The medium was then discarded and cells were incubated with different concentrations of the extract for 24 hours. After the incubation, medium was discarded and $100 \mu 1$ fresh medium was added with $10 \mu \mathrm{l}$ of MTT $5 \mathrm{mg} / \mathrm{ml}$. After 4 hours, the medium was discarded and $100 \mu 1$ of DMSO was added to dissolve the formazan crystals. Then, the absorbance was read at $570 \mathrm{~nm}$ in a microtitre plate reader. The assay was performed for all 10 fractions obtained from column chromatography. Cell survival was calculated by the following formula and the values are tabulated in Table 3 and respective cluster chart is shown in Fig.7. The $\mathrm{IC}_{50}$ values obtained are greater than 100 hence all the five synthesized compounds show moderate activity.

Viability $\%=$ Test OD/ Control OD X 100

$$
\text { Cytotoxicity } \%=100-\text { Viability } \%
$$

Table 3: Cytotoxicity Analysis of Hydrazone Derivatives of 2- Thioxodihydropyrimidine-2-Dione

\begin{tabular}{|c|c|c|c|c|c|c|}
\hline Sample & Concentration & Control & Sample & $\begin{array}{l}\text { \%of } \\
\text { viability }\end{array}$ & $\begin{array}{l}\% \text { pf } \\
\text { toxicity }\end{array}$ & $\begin{array}{l}\text { IC50 } \\
\text { value }\end{array}$ \\
\hline & Control & 1.121 & 1.121 & 100 & 0 & \\
\hline \multirow[t]{3}{*}{ PHTTO } & $50 \mu \mathrm{g}$ & 1.121 & 1.009 & 90.00 & 9.99 & 213.03 \\
\hline & $100 \mu \mathrm{g}$ & 1.121 & 0.912 & 81.35 & 18.64 & \\
\hline & $150 \mathrm{ug}$ & 1.121 & 0.853 & 76.09 & 23.90 & \\
\hline \multirow[t]{3}{*}{ DNPHTTO } & $50 \mu \mathrm{g}$ & 1.121 & 0.912 & 81.35 & 18.64 & 181.01 \\
\hline & $100 \mu \mathrm{g}$ & 1.121 & 0.861 & 76.80 & 23.19 & \\
\hline & $150 \mu \mathrm{g}$ & 1.121 & 0.731 & 65.20 & 34.79 & \\
\hline \multirow[t]{3}{*}{ ОТННРУНС } & $50 \mu \mathrm{g}$ & 1.121 & 0.951 & 84.83 & 15.16 & 173.8 \\
\hline & $100 \mu \mathrm{g}$ & 1.121 & 0.833 & 74.30 & 25.69 & \\
\hline & $150 \mu \mathrm{g}$ & 1.121 & 0.715 & 63.78 & 36.21 & \\
\hline \multirow[t]{3}{*}{ ОТТНРYHCT } & $50 \mu \mathrm{g}$ & 1.121 & 0.9001 & 80.29 & 19.70 & 171.41 \\
\hline & $100 \mu \mathrm{g}$ & 1.121 & 0.831 & 74.13 & 25.86 & \\
\hline & $150 \mu \mathrm{g}$ & 1.121 & 0.711 & 63.42 & 36.57 & \\
\hline \multirow[t]{3}{*}{ ОТТНРУВН } & $50 \mu \mathrm{g}$ & 1.121 & 1.004 & 89.56 & 10.43 & 204.3 \\
\hline & $100 \mu \mathrm{g}$ & 1.121 & 0.902 & 80.46 & 19.54 & \\
\hline & $150 \mu \mathrm{g}$ & 1.121 & 0.834 & 74.39 & 25.61 & \\
\hline
\end{tabular}



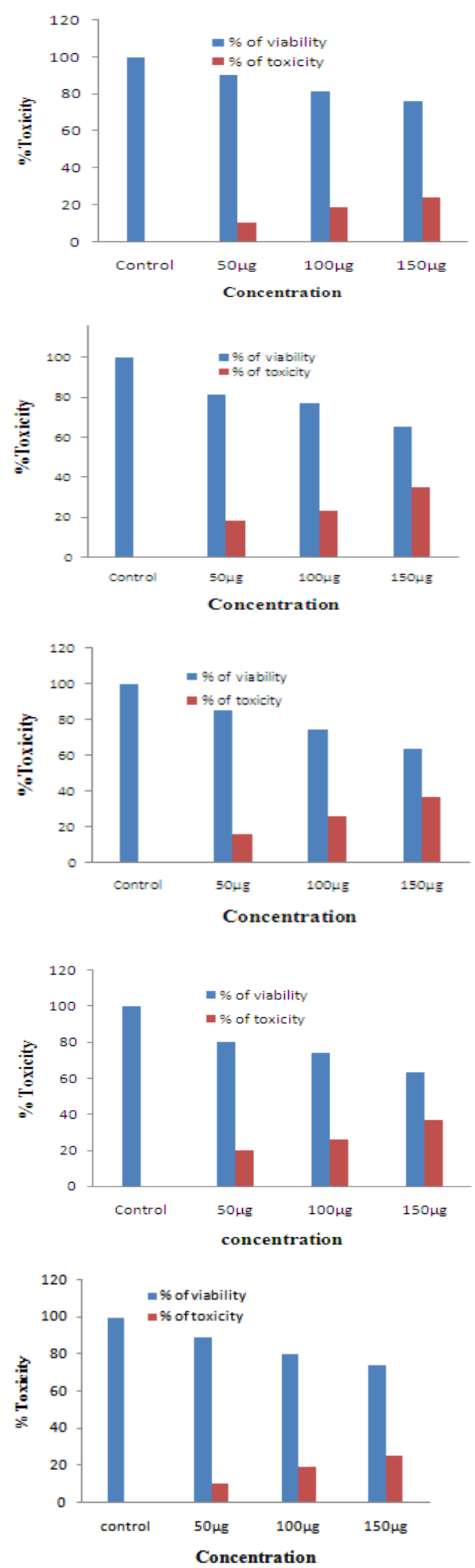

Fig. 7: Cluster Chart of Cytotoxicity Study of 2Thioxodihydropyrimidine-2-Dione Derivatives.

\section{Conclusion}

All the synthesized compounds were characterized by UV absorption which favours $\boldsymbol{\pi}-\boldsymbol{\pi}^{*}$ transition for compounds attached with phenyl group and $\mathrm{n}-\boldsymbol{\pi}^{*}, \mathrm{n}-\sigma^{*}$ for other substituted compounds with lone pair of electrons. IR frequencies were calculated which acts as a supportive information of the presence of functional group. NMR both ${ }^{1} \mathrm{H}$ and ${ }^{13} \mathrm{C}$ are used to calculate the total no. of protons and carbon atom present in synthesized compound. Biological study of the compound reveals good to moderate bacterial activity for all the synthesized compound and moderate to low activity for antifungal. The requirement of new drugs to kill infectious species that affects human and animals cells. Since the biological study shows moderate activity we performed toxicity study in addition to determine the toxic nature of the synthesized compound in order to conform the usage of synthesized compounds in drug field. And probably from the $\mathrm{IC}_{50}$ value obtained all the compounds show moderate activity and hence in future we focus to have a deep study of the compounds in medicinal and other fields.

\section{References}

[1] Kratz F., Beyer U., Collery P., 1998, Preparation, Characterization and in Vitro Efficacy of Albumin Conjugates of Doxorubicin, Biological \& Pharmaceutical Bulletin, 21, 1, 56-61. https://doi.org/10.1248/bpb.21.56.

[2] Imramovsky A., Polanc S., Kaustova J., 2007, A new modification of anti-tubercular active molecules, Bioorganic Medicinal Chemistry., 15, 7, 2551-2559. https://doi.org/10.1016/j.bmc.2007.01.051.

[3] Janin Y. L., 2007, Antituberculosis drugs: Ten years of research, Bioorganic Medicinal Chemistry., 15, 7, 2479 - 2513. https://doi.org/10.1016/j.bmc.2007.01.030.

[4] Salgin-Goksen U., Gokham-Keleci N., Goktas O., 2007, 1Acylthiosemicarbazides, 1,2,4-triazole-54H-thiones, 1,3,4thiadiazoles and hydrazones containing 5-methyl-2benzoxazolinones: Synthesis, analgesic-anti-inflammatory and antimicrobial activities, Bioorganic Medicinal Chemistry., 15, 17, 5738 - 5751. https://doi.org/10.1016/j.bmc.2007.06.006.

[5] Bhalla A., Sharma N., Jain S., 2006, HIV immunosupression and malaria: Is there a correlation, Indian Journal of Medical Sciences., $60,9,376$.

[6] Silva G.A., Costa L. M. M., Brito F. C. F., Fraga A.M., 2004, New class of potent antinociceptive and antiplatelet $10 \mathrm{H}$-phenothiazine1-acylhydrazone derivatives, Bioorganic Medicinal Chemistry., 12, 12, 3149-3158. https://doi.org/10.1016/j.bmc.2004.04.009.

[7] Savini L., Chiasserini L., Travagli V., Pellerano C., 2004, New $\alpha$ N-Heterocyclic hydrazones: Evaluation of Anticancer, anti-HIV, and Antimicrobial Activity, Chem Informatics., 35, 29. https://doi.org/10.1002/chin.200429138.

[8] Bijev A., 2006, New Heterocyclic Hydrazones in the Search for Antitubercular Agents: Synthesis and In Vitro Evaluations, Letters Drug Design \& Discovery., 3, 7, 506 - 512.

[9] Abdel- Aal M. T., El - sayed W. A., 2006, Synthesis and Antiviral Evaluation of Some Sugar Arylglycinoylhydrazones and Their Oxadiazoline Derivatives, Archiv der Pharmazie., 339, 12, 656 663.

[10] El-Hawash S.A.M., Abdel W.A.E., 2006, Cyanoacetic Acid Hydrazones of 3-and 4-Acetylpyridine and Some Derived Ring Systems as Potential Antitumor and Anti-HCV Agents, Archiv der Pharmazie., 339, 1, 14 - 23. https://doi.org/10.1002/ardp.200500161.

[11] Cocco M.T., Congiu C., Lilliu V., Onnis V., 2005, New Potential Anticancer Agents Based on the Anthranilic Acid Scaffold. Synthesis and Evaluation of Biological Activity, Journal of Medicinal Chemistry, 48, 26, 8245-8252. https://doi.org/10.1021/jm050711d.

[12] Malhotra M., Sharma R., Rathee D., Phogat P., 2014, Benzylidene /2-aminobenzylidene hydrazides: Synthesis, characterization and in vitro antimicrobial evaluation, Arabian Journal of Chemistry., 7, 5, 666 - 671. https://doi.org/10.1016/j.arabjc.2010.11.016.

[13] Long D. A., 2004, Infrared and Raman characteristic group frequencies. Journal of Raman Spectroscopy., 35, 10, 905.

[14] Wong K. C., 2015, Review of Spectrometric Identification of Organic Compounds, 8th Edition Spectrometric Identification of Organic Compounds, Journal of Chemical Education., 92, 10, 1602 1603. 
[15] Bauer A.W., Kirby W. M. M., Sherris J.C., Truck. M., 1966, Quality Control Testing with the Disk Antibiotic Susceptibility Test of Bauer-Kirby-Sherris-Turck, American Journal of Clinical Pathology, 45, 493-496.

[16] Mossman T., 1983, Rapid colorimetric assay for cellular growth and survival: Application to proliferation and cytotoxicity assays, Journal of Immunological Methods., 65, 1-2, 55-63. https://doi.org/10.1016/0022-1759(83)90303-4.

[17] Alley M.C., Lieber M.M., 1984, improved optical detection of colony enlargement and drug cytotoxicity in primary soft agar cultures of human solid tumour cells, British Journal of Cancer Research., 49, 2, 225-233. https://doi.org/10.1038/bjc.1984.35. 